\title{
DO SERBIAN BANKS MAKE OPTIMAL CORPORATE CREDIT DECISIONS?
}

\author{
Dalibor Jevtić1*, \\ Tamara Vesić1, \\ Lidija Barjaktarović ${ }^{2}$
}

${ }^{1} \mathrm{PhD}$ candidate Singidunum University, Belgrade, Serbia ${ }^{2}$ Singidunum University, Belgrade, Serbia
Correspondence:

Dalibor Jevtić

e-mail:

\begin{abstract}
:
In the matter of adequate Serbian banks' corporate credit decision-making process and fulfilment of customers' needs, this is a topic that involves a large number of potential and current banks' clients. Credit risk management theory proposes optimal combination of hard and soft facts for making adequate credit decision. The aim of the article is to stress that financial indicators should be analysed in the context of a company's overall business model on the sample of ten typical Serbian companies in the period of three fiscal years. Research results confirm that indicators such as turnover, number of employees, EBITDA and a company's equity are not enough to make final credit decision - approval or rejection. Furthermore, Serbian banks haven't made optimal credit decisions. However, new players on the financial market will have an impact on a company's business and structure of financial reports.
\end{abstract}

Keywords:

credit, banks, business, financial statements, indicators

\section{INTRODUCTION}

In all countries in the world, the financial system is regulated by international and local standards. International standards provide general frameworks beyond which the business of financial institutions is considered unregulated, while local standards (NBS, 2019), in accordance with international business frameworks, regulate the operation of financial institutions in more details (Cade, 1997). In addition to international and local standards, each bank has its own internal departments in charge of making sure all regulations are followed (i.e. compliance), and within them to spot their comparative advantage over their competition and to fulfil the requirements of their shareholders.

Credit risk management theory proposes optimal combination of hard (financial reports and financial instruments applied to it) and soft (ownership structure and reputation, management knowledge and ethic values, market position, etc.) facts when making adequate credit decision - approval or rejection (Barjaktarović, 2015). The aim of the article is to stress the importance of analyzing financial indicators in the context of a company's overall business model on the sample of ten companies in the period of three fiscal years. The subject of the research are ten selected corporate case studies, approved or denied on the basis of the chosen indicators.

By analyzing specific examples in the article and specific businesses, we will try to give suggestions as to how to improve banks' corporate credit decisionmaking process. Banks operate according to standard models (in accordance with 
regulation), which gives rise to the question whether it is appropriate to evaluate each business model separately, as well as whether it is sufficient to make a decision only on the basis of financial indicators (and proposed/predicted macroeconomic indicators for the Republic of Serbia). The increasingly stringent rules of the international and local regulators have led to the establishment of alternative players on financial market (such as microcredit institutions, funds, investors - companies and individuals, factoring, etc.), which take most of the profits and risks from the market (Benigno \& Robatto, 2019). The entry of new players on financial market will lead to consolidation of banking sector and creation of highly specialized banks. It is interesting to note that there are no detailed regulations on all other non-credit types of financing at global and international level, so there is room for machinations and excessive and rapid enrichment. The relationship between risk-adjusted internal debt metrics and corporate conservatism is slightly better for following companies: non-investment grade, experiencing credit rating downgrades, and high credit risk (Beckmanna et al., 2019).

The research h as five ch apters. In troduction co vers the subject and aim of the research. Literature review is presented in the second chapter. The third chapter covers methodology. Research results are in the fourth chapter. Conclusion is the last chapter of the research.

\section{LITERATURE REVIEW}

The business of each institution, including the financial one, is based on the adopted development strategy, presented in more details through plans and budgets on an annual basis (NBS, 2019). However,in practice there are situations where approved credits are not in accordance with a bank's credit risk policy.Credit policy involves an active participation of the banking system in the regulation of credit volume and its structure in economy (Mladenović \& Hadzić, 2014). Conventional approach suggests that greater competition in banking, by eroding bank charter values, exacerbates banks' incentives to take ex-cessive risks (Arping, 2019). It depends on the bank how strong the established risk management division is and whether it is in line with head-office abroad (currently, the majority of banks which perform business in Serbia are foreign-equity owned /NBS, 2019a/). Furthermore, it has direct impact on the achieved business result of the bank and its survival on the market. Finally, it has impact on shareholders decision for further activities.

It is important to stress that, in accordance with current regulations, in order to be considered as a stable and sustainable banking sector (i.e. financial sector, due to the fact that almost $93 \%$ of Serbian financial intermediaries are banks/NBS, 2019a/), banks on Serbian market must adjust its operations to the local market benchmark. Non-cooperatively set capital standards are higher than coordinated ones, and "race to the top" results, when governments care equally about banks' profits, taxpayers, and consumers (Haufler \& Maier, 2019). Due to these strong (credit risk management) constraints on the banking sector and their influence on financial markets in any country, it is a fact that not all clients get banks' loan (rejected cases) and they use more expensive sources of financing. For a few years, alternative financial institutions have been chasing those companies and offering unsecured loans and other financial instruments such as derivatives. Non-financial corporations typically cite risk management as the primary reason for their derivatives use. Moreover, if hedging programs are effective, then firms using derivatives should have lower credit risk in comparison to those which do not (Anbil et al., 2019).Finally, all participants on financial market should have and should work on improving financial literacy in order to use alternative sources of financing (Djulić et al., 2017).

\section{METHODOLOGY}

The sample of ten clients analyzed in this article are real companies that cooperated with the company Filinav d.o.o. Belgrade (financial consultant in charge for providing financing to companies and adviser to the business' owners) and whose credit requests were subject of Serbian banks. The companies names are made up of 3 letters (in order to protect data about real companies), wherein:

- The first letter C stands for Company,

- The second letter stands for the amount of revenue:A to $\mathrm{J}$ ( $\mathrm{A}$ is the smallest revenue, $\mathrm{J}$ is the largest revenue)

- The third letter stands for the size of a company:S small up to EUR 1 million revenue, $M$ - medium - up to EUR 30 million revenue, $\mathrm{L}$ - large - over EUR 30 million revenue.

Accordingly, the analysed companies are: CAS, CBS, CCS, CDS, CEM, CFM, CGM, CHM, CIM and CJL (presented in Table 1).Under each company name is the year of incorporation and the type of business. It is important to emphasize that Filinav cooperates with more than 40 companies. The relevant factors taken into consideration for making the sample are as follows: they didn't have any material overdue according to the Credit Bureau, experienced management, and in particular business, and good reputation of companies' owners. It is important to stress that the mentioned factors are important for a creditor. All analysed companies applied parallel to at least 10 local banks (2 domestic and 8 foreign-owned banks), so it can be considered that findings are valid for Serbian banking sector.

Indicators which will be taken into consideration are: turnover, number of employees, EBITDA (Earnings be- 
fore Interest Taxes and Depreciation) and equity. Chosen indicators are result of previous consultative experience and cooperation with corporate credit risk management departments of commercial banks. The sources of information are announced financial reports on the website of Serbian Business Registers Agency.

The analyzed period is three fiscal years /FY/ (the last fiscal year is 2018). Chosen FY's represent the FY before loan request, the FY when the credit decision was made, and the FY after credit decision. In the case of construction companies relevant years cycles were taken.

\section{Results and Discussion}

The following table presents basic data about the analyzed companies which are available in their financial reports and were part of set of documents for credit application.

Table 1 - Basic data of the analysed companies

\begin{tabular}{|c|c|c|c|c|c|c|c|c|c|c|}
\hline Company & Year & Equity & Loans & $\begin{array}{l}\text { EBIT- } \\
\text { DA }\end{array}$ & Emp. No. & WC & $\begin{array}{l}\text { WC } \\
\text { Ratio }\end{array}$ & \% Equity & $\begin{array}{l}\text { DEBT/ } \\
\text { EBITDA }\end{array}$ & $\%$ Profit \\
\hline CAS & 2016 & 12 & 1 & 19 & 4 & 53 & 1.8 & $7.4 \%$ & 0.1 & $3.4 \%$ \\
\hline 2013 & 2017 & 38 & 1 & 10 & 9 & 93 & 2.1 & $16.1 \%$ & 0.1 & $2.9 \%$ \\
\hline metal production & 2018 & 36 & 115 & 51 & 16 & -35 & 0.9 & $11.2 \%$ & 2.3 & $5.1 \%$ \\
\hline CBS & 2014 & 234 & 404 & 550 & 9 & 387 & 1.5 & $18.9 \%$ & 0.7 & $1.4 \%$ \\
\hline 2006 & 2016 & 200 & 451 & 44 & 11 & 227 & 1.2 & $15.3 \%$ & 10.3 & $3.5 \%$ \\
\hline construction & 2018 & 269 & 705 & 142 & 17 & 492 & 1.3 & $12.2 \%$ & 5.0 & $3.5 \%$ \\
\hline CCS & 2014 & 1 & 68 & 0 & 0 & 0 & 1.0 & $1.4 \%$ & 0.0 & $0.0 \%$ \\
\hline 2008 & 2016 & 17 & 43 & 20 & 9 & 16 & 1.0 & $1.6 \%$ & 2.2 & $3.0 \%$ \\
\hline development & 2018 & 98 & 107 & 75 & 10 & 106 & 1.0 & $4.0 \%$ & 1.4 & $4.1 \%$ \\
\hline CDS & 2016 & 20 & 46 & 31 & 18 & -94 & 0.8 & $4.3 \%$ & 1.5 & $1.7 \%$ \\
\hline 2010 & 2017 & 73 & 220 & 42 & 16 & -34 & 0.9 & $15.7 \%$ & 5.2 & $3.0 \%$ \\
\hline wholesale & 2018 & 73 & 189 & 781 & 17 & 49 & 1.0 & $5.8 \%$ & 0.2 & $0.1 \%$ \\
\hline CEM & 2016 & 16 & 0 & 343 & 5 & -215 & 0.9 & $0.9 \%$ & 0.0 & $0.4 \%$ \\
\hline 2014 & 2017 & 29 & 0 & 287 & 10 & -626 & 0.8 & $0.8 \%$ & 0.0 & $0.5 \%$ \\
\hline drugs production & 2018 & 43 & 0 & 99 & 19 & 938 & 1.4 & $1.0 \%$ & 0.0 & $0.6 \%$ \\
\hline CFM & 2014 & 174 & 2 & 134 & 43 & 171 & 1.9 & $48.2 \%$ & 0.0 & $18.9 \%$ \\
\hline 2012 & 2016 & 222 & 212 & 68 & 366 & 338 & 1.7 & $24.6 \%$ & 3.1 & $0.8 \%$ \\
\hline security & 2018 & 299 & 158 & 212 & 495 & 154 & 1.2 & $20.7 \%$ & 0.7 & $6.6 \%$ \\
\hline CGM & 2016 & 7 & 8 & 11 & 6 & 15 & 1.3 & $9.1 \%$ & 0.7 & $1.2 \%$ \\
\hline 2015 & 2017 & 96 & 97 & 117 & 10 & 80 & 1.7 & $27.1 \%$ & 0.8 & $3.1 \%$ \\
\hline recycling & 2018 & 2,359 & 118 & 485 & 12 & 530 & 4.0 & $84.2 \%$ & 0.2 & $2.6 \%$ \\
\hline CHM & 2014 & 48 & 0 & 47 & 30 & 357 & 1.9 & $5.8 \%$ & 0.0 & $3.3 \%$ \\
\hline 2014 & 2016 & 203 & 63 & 93 & 16 & 73 & 1.1 & $16.1 \%$ & 0.7 & $1.8 \%$ \\
\hline agro industry & 2018 & 395 & 260 & 225 & 20 & 386 & 1.4 & $23.1 \%$ & 1.2 & $3.2 \%$ \\
\hline CIM & 2012 & 1,577 & 5,056 & 1,663 & 128 & 3,605 & 2.5 & $19.5 \%$ & 3.0 & $8.4 \%$ \\
\hline 2001 & 2014 & 2,392 & 5,820 & 1,178 & 129 & 1,955 & 1.8 & $26.0 \%$ & 4.9 & $4.1 \%$ \\
\hline wholesale & 2018 & 4,540 & 5,548 & 1,574 & 119 & 1,210 & 1.3 & $32.8 \%$ & 3.5 & $4.9 \%$ \\
\hline CJL & 2011 & 24,020 & 48,599 & 15,319 & 266 & 4,283 & 1.1 & $21.8 \%$ & 3.2 & $7.7 \%$ \\
\hline 1989 & 2013 & 47,100 & 46,554 & 21,767 & 304 & 718 & 1.0 & $34.0 \%$ & 2.1 & $9.3 \%$ \\
\hline \multirow[t]{2}{*}{ cereal processing } & 2017 & 34,423 & 83,640 & 6,009 & 252 & $-24,439$ & 0.8 & $24.7 \%$ & 13.9 & $-1.1 \%$ \\
\hline & 2018 & 3,759 & 137,407 & $-1,977$ & 252 & 11,588 & 1.1 & $2.3 \%$ & -69.5 & $-29.0 \%$ \\
\hline
\end{tabular}

Source: Serbian Business Registers Agency; Authors 'calculations for indicators 
Legend:

WC - Working Capital is the difference between a company's current assets (such as cash, accounts receivable /customers' unpaid bills/ and inventories of raw materials and finished goods), and its current liabilities (such as accounts payable, short term loans, VAT liabilities).

WC Ratio- WC is presented as a relative proportion of current assets and current liabilities.

$\%$ Equity-calculated as absolute value of equity divided by total assets of the company and multiplied with 100 to be presented as a percentage.

DEBT/EBITDA- total short term and long-term loans divided with EBITDA.

$\%$ profit - net profit divided with total revenue, multiplied by 100 , to be presented as a percentage.

CAS - 95\% of metal production is for export only. CAS has all industry required certificates and permits in order to meet needs of customers all over the world. Furthermore, CAS has concluded long-term agreements for purpose-built production. After applying to different banks, 2 loans were approved, based on growing EBITDA on two year tenor covered by the mortgage. In 2019, CAS has engaged an advisor in order to get an adequately secured long-term loan which will improve the client's business. Banks didn't approve the loan due to the low equity and insufficient EBITDA (which is reasonable). Furthermore, they didn't accept as collateral assignment of incoming EU receivables based on exported goods which were higher than the requested loan amount.

CBS is a company with very long history in the construction industry, which is still in an upward trajectory in Serbia. The production cycle of construction of the facility, which is a minimum of 2 calendar years, must be observed. An additional problem for CBS was the account blockade requested by mistake by the tax authorities in 2013, which led to a lawsuit in 2019 that will be settledin favour of CBS. Since this was all easy to argue with, by hiring an advisor, banks were in favour of CBS in 2018, and with mortgages exceeding the value of the loan multiple times, a bigger loan amount was granted, covering the amount that the Tax Administration had taken from the client's business with the account blockade. CBS is an example of credit customer where market value of collateral was more important than expected revenues from sold property (subject of sale).

CCS is a company with experience in industry of property development based on partnership agreements with many companies on the project. Furthermore, they have respectable reference list. CCS financed their business by usage of a couple of very small collateralised loans. In 2019 they decided to obtain direct financing of the facility in order to earn extra profit.
Based on received offers for project financing and classical mid-term loan on 36 months (in the amount of EUR 300,000) they decided to use the second one. However, in spite of all the indicators, the bank established the mortgage on an existing facility (not subject of financing) and didn't have the understanding to monitor CCS' business.

CDS is a wholesaler with permanent problems of financing its business. The official financials presented a significant increase in revenue in 2017 and 2018, primarily due to the owner's decision to focus his business entirely on official cash flow. It had had an impact on increasing lending policy of commercial banks since 2017 until the beginning of 2019, without analysing what was the core of officially better standing of the company. In 2019 the owners decided to shut down the company due to various debts and penalties to tax authorities and employees. Accordingly, all debts toward bank will go in non-performing loans.

CEM meets all legal standards of the Republic of Serbia for the production of drugs and various supplements. It operates in the country and abroad. The customer base is very large and diversified. There are no overly dominant buyers. In 2018, CEM was ready to offer for long term loan as collateral: pledge on the equipment and assignment of future long-term receivables, cash collateral, and mortgage on the private property, corporate guarantee and bank's guarantee. However, not one of Serbian banks supported CEM's business due to the low equity. As can be noticed, CEM's business in 2018 had a positive trend in terms of profitability and liquidity.

CFM is a company which got long term fifteen-time higher unsecured credit on the basis of increasing indicators such as revenue and number of employees when comparing 2018 with 2017. However, in July 2019, CFM lost its most lucrative customer, which lead to a decrease in its monthly turnover by $50 \%$, and a reduction of its number of employees by 300 .

CGM is a company with similar credit history compared to CFM. Their credit unsecured debt increased by three times in one calendar year. In this case, profitability was completely neglected. The capital increase was carried out by recapitalization.

CHM's activity is very popular in Serbia and gladly funded. By 2018, CHM had a very big problem securing its financing because it was relatively new to the market. In 2017, the company finished positively and met the basic financial parameters that the bank is observing, so borrowing started in 2018. In February 2019 the company received a loan in the amount of EUR 150,000 and the total debt has increased to cc EUR 400,000. As of March $11,2019, \mathrm{CHM}$ has been in a blockade and bankruptcy proceedings have been initiated against it. 
CIM is experienced in wholesale business, including good reputation of owners and management. Their financial indicators were respectable. Before 2014, CIM got collateralized loan by mortgage with 24 months maturity with unfavourable terms and conditions (in terms of tenor and interest rate). After engaging consultants and improving financial reporting, CIM got unsecured long-term financing in 2019.

$\mathrm{CJL}$ is an example, according to the authors of this paper, of the company which is in the category "too big to fail" in Serbia. According to financial indicators CJL was a good credit customer by 2013. During 2014 there were obvious problems in repayment of credit installments. Furthermore, indicators such as a negative EBITDA, decrease of equity, 3-times debt increase in 2018 compared to 2013 and a $17 \%$ decrease in the number of employees stressed categorization of CJL as "too big to fail".

Based on the analysed companies, it can be concluded that majority of credit decisions were made mainly on the basis of financial indicators or the market value of the offered collateral. Furthermore, it can be noticed that the companies didn't get proper financing due to the lack of the banks' employees or their ethic values. Finally, it can be said that the proper combination of hard and soft facts wasn't in place for making the final corporate credit approval decision.

\section{CONCLUSION}

The research showed that Serbian banks didn't make optimal corporate credit decisions. It was the result of inadequate knowledge of banks' employees or their ethic values. Their focus was on financial indicators. This implies that banks should take into account that permanent education of their employees is required, including product specific knowledge as well as ethic principles. Furthermore, yearly checking and testing of employees should be done, in order to get better credit decisions and provide optimal credit portfolio. However, the described situation on banking market, makes room for new alternative players on financial market which are less conservative and risk oriented.

The problem arises with Serbian banks; hence they want to have balances that are optimal at the cross-section, which is generally on $12 / 31$ every year, and have no hearing for businesses that are seasonal or specific. This is obvious in the case of construction companies which don't get project financing, but classical credit lines for working capital which is not in line with revenue generation and accordingly with the requested collateral. Furthermore, the current environment allows for selling property in cash directly to the investor, which has an impact on the the amount of illegal money in circulation and other types of financing which out of the organized and supervised market.

It can be noticed that Serbian banks don't have the proper understanding of cross-selling (connected through approved loan) and satisfaction of customer needs, in terms of defined account inclusion, employees' pay-roll accounts and other connected products. Developing financial systems and the turbulent business environment are subject to daily changes, forcing financial institutions to adapt quickly to ever changing circumstances (Dimić \& Barjaktarović, 2017).

There is room for further improvement of Serbian banks' offer and knowledge of employees.

\section{ACKNOWLEDGMENT}

This Research Paper was the part of the project "Advancing Serbia's Competitiveness in the Process of EU Accession", no. 47028, in the period 2011-2019, financed by the Serbian Ministry of Science and Technological Development.

\section{REFERENCES}

1. Anbila, S., Sarettob, A., Tookesc, H. (2019). How does hedge designation impact the market's perception of credit risk?Journal of Financial Stability, Vol. 41, 25-42.

2. Arping, S. (2019). Competition and risk taking in banking: The charter value hypothesis revisited. Journal of Banking \& Finance, pp. in progress, doi:https://doi. org/10.1016/j.jbankfin.2019.105609

3. Barjatkarović, L. (2015) Risk Management, Singidunum University, Belgrade

4. Beckmanna, K., Escobarib, D., Ngo., T. (2019). The real earnings management of cross-listing firms. Global Finance Journal, Vol. 41, 128-145.

5. Benigno, P., Robatto,R. (2019). Private money creation, liquidity crises, and government interventions. Journal of Monetary Economics, pp. in progress, doi: https://doi. org/10.1016/j.jmoneco.2019.07.005

6. Cade, E. (1997). Managing Banking Risks - 1st edition. Woodhead Publishing

7. Dimić, M., Barjaktarović, L. (2017). Vlasnička transformacija bankarskog sektora u zemljama jugoistocne Evrope. Bankarstvo, Vol. 46 (1), 84-103.

8. Djulić, K., Barjaktarović, L., Pindzo, R., Vejtrov,A. (2017) Analysis of the capital structure decisions: a survey on Serbian companies, Ekonomikapreduzeca, No. 5-6, pp. 355 - 364

9. Serbian Business Registers Agency(2019) Financial reports of analysed companies, http://pretraga3.apr.gov. rs/pretragaObveznikaFI

10. Haufler, A., Maier, U. (2019). Regulatory competition in capital standards: a 'race to the top' result. Journal of Banking \& Finance, Vol. 106, 180-194.

11. Mladenović, V., Hadžić, M. (2014). Monetary and foreign currency policy of the European central bank. Singidunum Journal of Applied Sciences, 11(1), 16-24.

12. National Bank of Serbia/NBS/ (2019) Decision on classification of balance sheet assets and off-balance sheet items of the bank,http://www.nbs.rs/internet/cirilica/20/index_kpb.html

13. National Bank of Serbia /NBS/ (2019a) Serbian Banking Sector - Report on the third quartile of 2018, http://www.nbs.rs/ internet/latinica/55/55_4/kvartalni_izvestaj_III_18.pdf

14. Decision on Risk Management by Banks,http://www.nbs. rs/internet/cirilica/20/index_kpb.html 